\title{
Kemampuan Membaca Efektif Siswa Kelas X SMA Negeri Kota Bengkulu
}

\author{
Meddyan Heriadi ${ }^{\square}$ \\ ${ }^{1}$ Institut Agama Islam Negeri (IAIN) Bengkulu \\ ${ }^{1}$ meddyan@iainbengkulu.ac.id
}

Abstract : Bahasa Indonesia is one of the basic subjects for other fields of science. One of these basic abilities is speed reading skills. Therefore, if the teacher fails to teach this ability, the students will certainly be lazy to read. The purpose of this research is to describe the effective reading ability of class X SMA Negeri Bengkulu City school in academic year 2011/2012 in understanding discourse. The population in this study were 10 Senior High Schools at grade ten in the academic year 2011/2012. The samples taken were chosen from high, medium, and low accredited schools which used purposive sampling technique. This research employed quantitative descriptive methods. From the results of the study, it can be illustrated that the average effective reading ability of class $X$ students of Bengkulu City High School was 156,8662 words per minute. Nonetheless, it is classified as less feasible. This still has not achieved the expected competencies in the School-based Curriculum (KTSP) which demands 250 words per minute, so that the average reading capability of class X high school students in Bengkulu is still relatively slow (insufficient).

Keywords: effective reading, reading, literacy, bahasa indonesia

Abstrak : Mata pelajaran bahasa Indonesia merupakan salah satu mata pelajaran dasar bagi bidang ilmu lain. Salah satu kemampuan dasar tersebut adalah keterampilan membaca cepat. Oleh karena itu, jika guru gagal mengajarkan kemampuan ini, maka murid pastinya akan malas untuk membaca. Tujuan penelitian ini adalah untuk menggambarkan kemampuan membaca efektif siswa kelas X SMA Negeri Kota Bengkulu tahun ajaran 2011/2012 dalam memahami wacana. Populasi yang diambil dalam penelitian ini adalah siswa SMA Negeri kota Bengkulu kelas X tahun ajaran 2011/2012 dengan jumlah SMA Negeri di Kota Bengkulu terdapat 10 sekolah. Sampel yang diambil adalah sekolah yang berakreditasi tinggi, sedang, dan rendah yang diambil dengan menggunakan teknik purposive sampling. Penelitian ini menggunakan metode deskriptif kuantitatif. Jadi, dapat disimpulkan bahwa rata-rata pemahaman siswa kelas X SMA N Kota Bengkulu adalah 70,03\% dan rata-rata Kemampuan membaca efektif (KME) siswa kelas X SMA N Kota Bengkulu adalah 156,09 kata per menit. Hal ini masih belum mencapai kompetensi yang diharapkan dalam Kurikulum Tingkat Satuan Pendidikan (KTSP) yang menuntut 250 kata per menit, sehingga rata-rata Kemampuan Membaca efektif siswa kelas X SMA N Kota Bengkulu masih tergolong lambat (kurang memadai).

Kata Kunci : kemampuan membaca, membaca efektif, bahasa indonesia, literasi

Sitasi Artikel:

Heriadi, M. (2020). Kemampuan Membaca Efektif Siswa Kelas X SMA Negeri Kota Bengkulu. Disastra: Jurnal Pendidikan Bahasa dan Sastra Indonesia, 2(2), 141-153. doi:http://dx.doi.org/10.29300/disastra.v2i2.3016 


\section{Pendahuluan}

Masyarakat zaman dahulu percaya bahwa unsur keberuntungan memegang peranan penting dalam kehidupan. Namun, sekarang ini orang yang berhasil adalah orang yang mampu menguasai informasi. Dewasa ini, beberapa instansi seperti instansi pendidikan mulai menugasi para guru untuk melakukan penelitian tindakan kelas sehingga seorang guru dituntut untuk memiliki kemampuan membaca efektif agar dapat menguasai informasi. Sementara itu, waktu yang tersedia makin terbatas. Semua harus berpacu dengan informasi yang setiap hari bermunculan. Jika tidak, maka kita akan kehilangan informasi tersebut.

Persaingan antarindividu cukup ketat dalam segala hal baik dalam dunia pekerjaan, hobi, dan pendidikan. Dalam dunia pekerjaan, semua orang berlomba untuk menaikkan pangkat. Dalam dunia pendidikan, semua murid berlomba untuk mendapat nilai terbaik; dan dalam dunia hobi para seniman misalnya, mereka berlomba untuk menjadi yang paling unik dan kreatif. Semua itu membutuhkan pengetahuan dan pengetahuan diperoleh dari membaca sehingga kemampuan ini tidak boleh dianggap remeh.

Pada kenyataannya, sekarang ini masih terdengar beberapa keluhan bahwa kemampuan bahasa Inggris para siswa masih terlalu lemah sehingga mereka takut pada buku-buku berbahasa Inggris. Ternyata lebih dari itu, terhadap buku-buku berbahasa Indonesia pun mereka takut, terlalu lama untuk menyelesaikan buku-buku yang tipis sekalipun. Namun bagaimana mengelola sebuah buku dengan ketebalan 300 halaman, dengan 350.000 kata? Padahal, yang kita perlukan hanya beberapa pokok kata dari buku tersebut. Dengan skimming dan scanning seseorang mampu mengetahui informasi penting yang dibutuhkan dengan cepat. Sesungguhnya tidak setiap kata yang tercetak dalam buku harus dibaca dan tidak semua detail buku harus dipelajari. Apa yang tercetak belum tentu benar dan belum tentu berharga untuk dibaca. Bahkan sekalipun validitasnya telah teruji, tidak dengan sendirinya lantas bermanfaat untuk kita baca.

Penguasaan siswa terhadap keterampilan membaca dianggap masih lemah, tentu saja bukan karena tidak ada alasan yang jelas (Andra, 2019). Terkadang muncul beberapa keluhan akan kesulitan dalam membaca efektif. Seolah kegiatan membaca adalah sesuatu yang spesial yang membutuhkan banyak prasyarat. Padahal secara disadari atau pun tidak, hampir setiap kita melakukan aktivitas membaca. Ketika di jalan kita melihat baliho atau poster, secara otomatis kita telah membacanya. Akan tetapi, kita begitu enggan membaca buku, apalagi buku dengan ketebalan beratus-ratus halaman. Di samping itu, mata pelajaran bahasa Indonesia merupakan salah satu mata pelajaran dasar bagi bidang ilmu lain karena bahasa Indonesia meliputi kemampuan berbahasa, yaitu: membaca, menyimak, berbicara, dan menulis. Oleh karena itu, apapun bidang ilmunya sangat membutuhkan kemampuan membaca dan menyimak untuk mengembangkan pengetahuan.

Pemerintah Daerah Kota Bengkulu tengah menggalakkan Bengkulu sebagai kota pelajar. Gerakan literasi juga terus 
dilakukan oleh pemerintah untuk dapat meningkatkan minat baca siswa. Gerakan Sadar Literasi yakni meningkatkan minat baca secara luas dan membantu terwujudnya agenda prioritas (Nawacita) pemerintah (Eliya, 2019). Salah satu bidang yang mendapat pengaruh besar dari membaca adalah pendidikan (Friantary, 2019). Hal ini mengisyaratkan bahwa kemampuan belajar siswa adalah hal yang utama yang mestinya dibarengi dengan kemampuan membaca. Oleh karena itu, peneliti tertarik untuk meneliti bagaimana kemampuan membaca cepat siswa yang khususnya kelas $\mathrm{X}$ di Kota Bengkulu. Sekolah yang dipilih dalam penelitian ini merupakan perwakilan dari sekolah-sekolah yang terakreditasi tinggi, sedang, dan rendah.

\section{Metode Penelitian}

Masalah dalam penelitian ini adalah bagaimana kemampuan membaca efektif siswa kelas X SMA Negeri Kota Bengkulu tahun ajaran 2011/2012? Tujuan penelitian ini adalah untuk menggambarkan kemampuan membaca efektif siswa kelas $\mathrm{X}$ SMA Negeri Kota Bengkulu tahun ajaran 2011/2012. Metode yang dipakai dalam penelitian ini, yaitu metode deskriptif kuantitatif. Sebagaimana menurut Syamsudin (2007:24) metode deskriptif kuantitatif merupakan suatu metode penelitian yang bertujuan menjelaskan fenomena yang ada dengan menggunakan angka-angka untuk menggambarkan karakteristik individu atau kelompok.

Populasi yang diambil dalam penelitian ini adalah siswa SMA Negeri kota Bengkulu kelas $\mathrm{X}$ tahun ajaran 2011/2012 dengan jumlah SMA Negeri di Kota Bengkulu 10 sekolah dan jumlah siswa kelas $\mathrm{X}$ adalah 2225 (Dinas Pendidikan Nasional Kota Bengkulu 2011). Pengambilan sampel menggunakan teknik purposive sampling. Sugiono (2009:124) memaparkan bahwa teknik purposive sampling adalah teknik penentuan sampel berdasarkan suatu pertimbangan tertentu. Dasar pertimbangannnya adalah terdapat 10 SMA yang ada di Kota Bengkulu. Dari 10 sekolah tersebut, dibagi ke dalam beberapa kategori, (1) kategori nilai akreditasi sekolah tinggi, (2) kategori nilai akreditasi sekolah menengah, dan (3) kategori nilai akreditasi sekolah terendah

Tabel 1: Akreditasi SMA di Kota Bengkulu

\begin{tabular}{|l|c|c|l|}
\hline Nama Sekolah & $\begin{array}{l}\text { Nilai } \\
\text { Akreditasi }\end{array}$ & $\begin{array}{l}\text { Peringkat } \\
\text { akreditasi }\end{array}$ & Ket. \\
\hline SMAN 2 & 98.63 & A & Tinggi \\
\hline SMAN 5 & 97.99 & A & \\
\hline SMA Plus N 7 & 93.43 & A & \\
\hline SMA N 6 & 93.40 & A & \\
\hline SMAN 3 & 90.51 & A & \\
\hline SMA N 1 & 90.5 & A & Menengah \\
\hline SMA N 8 & 87.72 & A & \\
\hline SMA N 4 & 86.65 & A & \\
\hline SMA N 9 & 81.9 & B & \\
\hline SMA N 10 & 73.5 & B & Rendah \\
\hline
\end{tabular}

(www.bansm.or.id/provinsi/bengkulu/akredi tasi)

Berdasarkan tabel di atas, maka cara memilih sampel adalah sampling stratifikasi. Peneliti mengunakan teknik ini karena dalam populasi terdapat 3 kategori, yaitu: tinggi, sedang, dan rendah. Kategori ini sudah mewakili populasi SMA Negeri kota bengkulu yang berkualitas tinggi, sedang, dan rendah. Jadi, sekolah akan yang menjadi sampel penelitian adalah 3 sekolah yang masing-masing sekolah akan diambil 1 kelas, yaitu: SMA N 2 Kota Bengkulu sebanyak 26 siswa, SMA N 1 Kota 
Volume 2, Nomor 2, Juli 2020

ISSN 2655-3031 (P), 2655-7851 (O)

Bengkulu sebanyak 27 siswa, dan SMA N 10 Kota Bengkulu sebanyak 34 siswa .

Sementara itu, teknik pengumpulan data dalam penelitian ini adalah teknik tes yang dipakai untuk menguji kemampuan membaca efektif siswa. Data yang akan diambil adalah lama membaca sisiwa dan nilai pemahamann siswa. Selanjutnya, teknik angket digunakan untuk menggambarkan kebiasaan membaca siswa dan teknik wawancara dilakukan kepada guru kelas yang menjadi objek penelitian yang bertujuan untuk mengetahui metode yang digunakan oleh guru dalam meningkatkan kemampuan membaca efektif siswa. Wawancara dilaksanakan secara terbuka dan bebas. Hal ini dimaksudkan agar guru tidak merasa terbebani oleh pertanyaan-pertanyaan peneliti.

Instrumen tes dalam penelitian ini menggunakan beragam wacana teks untuk dibaca karena setiap orang memiliki kemampuan yang berbeda-beda dalam membaca dengan tema tertentu. Materimateri tersebut antara lain Untuk Maju Kita Harus Melihat Ke Depan (318 kata), Sukhoi Tiba, Sayang tanpa Kosmonot (350 kata), Kekeringan Lebih Berbahaya dari Banjir (316 kata), Hagemoni Jepang (327 kata), Islam Cinta Pertamanya (318 kata), Manfaat Nanas Untuk Kesehatan (307 kata), Tsunami di Aceh (344 kata). Sementara itu, bentuk alat tes yang digunakan untuk mengukur pemahaman siswa adalah:(a). Kemampuan mengidentifikasi kata; (b). Kemampuan mengantisipasi makna; (c) Kemampuan menyimpulkan maksud penulis; (d). Kemampuan mengidentifikasi struktur penulisan.

Selanjutnya teknik analisis data dalam penelitian ini adalah penilaian kecepatan membaca efektif dengan rumus:

Jumlah kata

$\overline{\text { Lama baca }(\text { Menit })}=$ jumlah $\mathrm{kpm}$

(Tampubolon, 1990:244)

Mengukur pemahaman isi wacana dapat dilakukan dengan rumus :

Jumlah benar

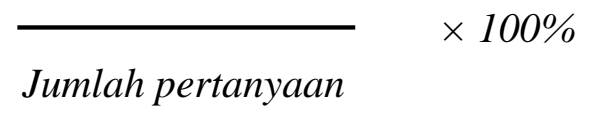

Kriteria yang digunakan untuk melihat pemahaman siswa adalah:

$>70 \%=$ Memadai $/$ cukup

$<70 \%$ = belum memadai/cukup

(Tampubolon, 1990:244)

a. Mengukur Kemampuan membaca efektif dapat menggunakan rumus:

Kecepatan membaca $\times$ Pemahaman

(Tampubolon, 1990:244)

b. Mengukur rata-rata Kemampuan membaca efektif siswa

$$
\mathrm{M}=\frac{\sum X}{N}
$$

$\mathrm{M}=$ Nilai rata-rata

$\sum X=$ Jumlah kecepatan membaca siswa

$\mathrm{N}=$ Jumlah sampel

(Nurgiantoro, 1995:355)

Kriteria yang digunakan untuk melihat Kemampuan membaca berdasar standar isi 
Volume 2, Nomor 2, Juli 2020 ISSN 2655-3031 (P), 2655-7851 (O)

Kurikulum Tingkat Satuan Pendidikan (KTSP) dasar dan menengah. Salah satu Kompetensi Dasar (KD) yang harus dimiliki siswa kelas $\mathrm{X}$ dalam membaca efektif adalah 250 kata per menit (KPM) (Mulyasa, 2006:53).

$\leq 250$ kata permenit $\rightarrow$ tidak memadai

$\geq 250$ kata permenit $\rightarrow$ memadai/ cukup

\section{Hasil dan Pembahasan}

Hasil penelitian diklasifikasikan menjadi tiga kelompok, yaitu: 1) kecepatan membaca efektif siswa kelas $\mathrm{X}$ yang menyangkut pemahaman dan kecepatan membaca siswa; 2) kebiasaan-kebiasaan membaca siswa yang berasal dari angket; dan 3) metode pengajaran membaca efektif yang digunakan oleh guru.

\section{Kecepatan Membaca Efektif Siswa}

a. Kecepatan Membaca Efektif Siswa SMA N 10 Kota Bengkulu

UJI KME yang dilaksanakan di SMA N 10 Kota Bengkulu dilakukan sebanyak 7 kali dalam satu pertemuan. Pada uji KME pertama, diikuti sebanyak 34 siswa yang diberikan teks dengan judul Untuk Maju Kita harus Melihat ke Depan yang terdiri atas 318 kata. Dari tes ini diketahui rata-rata waktu siswa dalam membaca adalah 1,67 menit, rata-rata pemahaman siswa adalah $55,29 \%$, dan ratarata Kemampuan Membaca Efektif siswa adalah 107,06 KPM. Dari data rata-rata uji kemampuan membaca efektif siswa yang pertama dapat disimpulkan bahwa kemampuan membaca efektif siswa masih tergolong lambat (kurang memadai), karena tuntutan kemampuan membaca efektif siswa berdasarkan Kurikulum Tingkat Satuan Pendidikan (KTSP) adalah 250 kata per menit.

Pada uji KME kedua, siswa diberikan teks dengan judul "Sukhoi Tiba, Sayang tanpa Kosmonot" yang terdiri atas 350 kata. Dari tes kedua ini, waktu yang dibutuhkan oleh siswa dalam membaca adalah 1,67 menit dengan rata-rata pemahaman siswa mengalami penurunan dari uji KME sebelumnya menjadi 51,76\% dan rata-rata KME siswa mengalami peningkatan dari uji KME sebelumnya menjadi 112,244 KPM. Jadi, pada uji KME kedua ini dapat disimpulkan bahwa Kemampuan Membaca Efektif siswa masih lambat (kurang memadai).

Pada hasil uji KME ketiga, teks yang diberikan berjudul "Kekeringan Lebih Berbahaya dari Banjir" yang terdiri atas 316 kata. Rata-rata waktu yang digunakan adalah 1,49 menit, rata-rata pemahaman adalah $55,29 \%$ dan rata-rata Kemampuan Membaca Efektif siswa adalah 128,73 KPM. Rata-rata Kemampuan Membaca Efektif ini masih belum mencapai kompetensi yang diharapkan dalam Kurikulum Tingkat Satuan Pendidikan (KTSP), sehingga Kemampuan Membaca Efektif siswa pada uji KME ketiga ini masih tergolong lambat (kurang memadai).

Pada uji KME keempat, teks berjudul "Hagemoni Jepang" yang terdiri atas 327 kata. Rata-rata waktu yang dibutuhkan dalam membaca adalah 2,92 menit, rata-rata pemahaman siswa adalah $66,47 \%$, dan rata-rata Kemampuan Membaca Efektif siswa adalah 142,99 KPM. Jadi, rata-rata Kemampuan Membaca Efektif 
Volume 2, Nomor 2, Juli 2020 ISSN 2655-3031 (P), 2655-7851 (O)

siswa masih tergolong lambat (kurang memadai).

Pada uji KME kelima, wacana yang digunakan terdiri atas 318 katayang berjudul "Islam Cinta Pertamanya". Rata-rata waktu yang digunakan oleh siswa adalah 1,45 menit, rata-rata pemahaman siswa mengalami peningkatan cukup signifikan yang menjadi $97,64 \%$ dan rata-rata Kemampuan Membaca Efektif siswa adalah 22,49 KPM, sehingga dapat disimpulkan bahwa Kemampuan membaca efektif siswa masih tergolong lambat (kurang memadai).

Uji KME keenam, wacana terdiri atas 307 kata dengan judul "Manfaat Nanas untuk Kesehatan". Rata-rata waktu yang digunakan siswa adalah 1,264 menit, ratarata pemahaman siswa adalah $76,47 \%$, dan rata-rata Kemampuan membaca efektif siswa adalah 190,91 KPM, jadi dapat disimpulkan bahwa Kemampuan membaca efektif siswa masih tergolong lambat (kurang memadai).

Pada uji KME terakhir, teks terdiri atas 344 kata dengan judul "Tsunami di Aceh". Rata-rata waktu yang diperlukan siswa untuk membaca adalah 1,67 menit, rata-rata pemahaman siswa adalah $84,7 \%$, dan rata-rata Kemampuan membaca efektif siswa adalah 233,71 KPM. jadi dapat disimpulkan bahwa Kemampuan membaca efektif siswa masih tergolong lambat (kurang memadai).

Dari 7 kali uji KME yang telah dilaksanakan menunjukan bahwa rata-rata waktu yang digunakan untuk membaca adalah 1,68 menit, rata-rata pemahaman adalah $69,66 \%$, dan rata-rata Kemampuan membaca efektif siswa adalah 162,59 KPM. jadi dapat disimpulkan bahwa, rata-rata
Kemampuan membaca efektif siswa SMA N 10 kelas Xa masih tergolong lambat (kurang memadai).

\section{b. Kecepatan Membaca Efektif Siswa SMA N 1 Kota Bengkulu}

Uji KME yang dilaksanakan di SMA N 1 Kota Bengkulu dilakukan sebanyak 7 kali dalam satu pertemuan. Pada uji KME pertama, diikuti sebanyak 27 siswa yang diberikan teks dengan judul Untuk Maju Kita harus Melihat ke Depan yang terdiri atas 318 kata. Dari tes ini diketahui rata-rata waktu siswa dalam membaca adalah 1,602 menit, rata-rata pemahaman siswa adalah 52,59\%, dan ratarata Kemampuan membaca efektif siswa adalah 109,24 KPM. Dari data rata-rata uji Kemampuan Membaca efektif siswa yang pertama dapat disimpulkan bahwa Kemampuan membaca efektif siswa masih tergolong lambat (kurang memadai), karena tuntutan Kemampuan membaca efektif siswa berdasarkan Kurikulum Tingkat Satuan Pendidikan (KTSP) adalah 250 kata per menit.

Pada uji KME kedua, siswa diberikan teks dengan judul "Sukhoi Tiba, Sayang tanpa Kosmonot" yang terdiri dari 350 kata. Dari tes kedua ini, waktu yang dibutuhkan oleh siswa dalam membaca adalah 1,88 menit dengan rata-rata pemahaman siswa mengalami penurunan dari uji KME sebelumnya menjadi 39,25\% dan rata-rata KME siswa juga mengalami penurunan dari uji KME sebelumnya menjadi 75,36 KPM. Jadi, pada uji KME kedua ini dapat disimpulkan bahwa Kemampuan membaca efektif siswa masih 
Volume 2, Nomor 2, Juli 2020 ISSN 2655-3031 (P), 2655-7851 (O)

lambat (kurang memadai).

Pada hasil uji KME ketiga, teks yang diberikan berjudul "Kekeringan Lebih Berbahaya dari Banjir" yang terdiri atas 316 kata. Rata-rata waktu yang digunakan adalah 1,78 menit, rata-rata pemahaman adalah 26,6\% dan rata-rata Kemampuan membaca efektif siswa adalah 48,28 KPM. Rata-rata Kemampuan membaca efektif ini masih belum mencapai kompetensi yang diharapkan dalam Kurikulum Tingkat Satuan Pendidikan (KTSP), sehingga Kemampuan membaca efektif siswa pada uji KME ketiga ini masih tergolong lambat (kurang memadai).

Pada uji KME keempat, teks berjudul "Hagemoni Jepang" yang terdiri dari 327 kata. Rata-rata waktu yang dibutuhkan dalam membaca adalah 1,97 menit, rata-rata pemahaman siswa adalah 60 $\%$, dan rata-rata Kemampuan membaca efektif siswa adalah 105,25 KPM. Jadi, rata-rata Kemampuan membaca efektif siswa masih tergolong lambat (kurang memadai).

Pada uji KME kelima, wacana yang digunakan terdiri atas 318 kata yang berjudul "Islam Cinta Pertamanya". Ratarata waktu yang digunakan oleh siswa adalah 1,83 menit, rata-rata pemahaman siswa mengalami peningkatan cukup signifikan yang menjadi $89,23 \%$ dan ratarata Kemampuan membaca efektif siswa adalah 162,08 KPM, sehingga dapat disimpulkan bahwa Kemampuan membaca efektif siswa masih tergolong lambat (kurang memadai).

Uji KME keenam, wacana terdiri atas 307 kata dengan judul "Manfaat Nanas untuk Kesehatan”. Rata-rata waktu yang digunakan siswa adalah 1,66 menit, rata-rata pemahaman siswa adalah $68,88 \%$, dan ratarata Kemampuan membaca efektif siswa adalah 138,18 KPM, jadi dapat disimpulkan bahwa Kemampuan membaca efektif siswa masih tergolong lambat (kurang memadai).

Pada uji KME terakhir, teks terdiri atas 344 kata dengan judul "Tsunami di Aceh". Rata-rata waktu yang diperlukan siswa untuk membaca adalah 1,70 menit, rata-rata pemahaman siswa adalah $69 \%$, dan rata-rata Kemampuan membaca efektif siswa adalah 144,4 KPM. jadi dapat disimpulkan bahwa Kemampuan membaca efektif siswa masih tergolong lambat (kurang memadai).

Dari 7 kali uji KME yang telah dilaksanakan menunjukan bahwa rata-rata waktu yang digunakan untuk membaca adalah 1,77 menit, rata-rata pemahaman adalah $57,93 \%$, dan rata-rata Kemampuan membaca efektif siswa adalah 111,82 KPM. Jadi dapat disimpulkan bahwa, rata-rata Kemampuan membaca efektif siswa SMA $\mathrm{N} 10$ kelas Xc masih tergolong lambat (kurang memadai).

\section{c. Kecepatan Membaca Efektif Siswa SMA N 2 Kota Bengkulu}

Uji KME yang dilaksanakan di SMA N 2 Kota Bengkulu dilakukan sebanyak 7 kali dalam satu pertemuan. Dari pelaksanaan uji KME tersebut, hasilnya dapat digambarkan sebagai berikut. Pada uji KME pertama, diikuti sebanyak 26 siswa yang diberikan teks dengan judul Untuk Maju Kita harus Melihat ke Depan yang terdiri atas 318 kata. Dari tes ini diketahui rata-rata waktu siswa dalam membaca 
Volume 2, Nomor 2, Juli 2020 ISSN 2655-3031 (P), 2655-7851 (O)

adalah 1,37 menit, rata-rata pemahaman siswa adalah $68,46 \%$, dan rata-rata Kemampuan membaca efektif siswa adalah 152,36 KPM. Dari data rata-rata uji Kemampuan membaca efektif siswa yang pertama dapat disimpulkan bahwa Kemampuan membaca efektif siswa masih tergolong lambat (kurang memadai), karena tuntutan Kemampuan membaca efektif siswa berdasarkan Kurikulum Tingkat Satuan Pendidikan (KTSP) adalah 250 kata per menit.

Pada uji KME kedua, siswa diberikan teks dengan judul "Sukhoi Tiba, Sayang tanpa Kosmonot" yang terdiri atas 350 kata. Dari tes kedua ini, waktu yang dibutuhkan oleh siswa dalam membaca adalah 1,73 menit dengan rata-rata pemahaman siswa mengalami peningkatan dari uji KME sebelumnya menjadi $85,38 \%$ dan rata-rata KME siswa juga mengalami peningkatan dari uji KME sebelumnya menjadi 174,42 KPM. Jadi, pada uji KME kedua ini dapat disimpulkan bahwa Kemampuan membaca efektif siswa masih lambat (kurang memadai).

Pada hasil uji KME ketiga, teks yang diberikan berjudul "Kekeringan Lebih Berbahaya dari Banjir" yang terdiri atas 316 kata. Rata-rata waktu yang digunakan adalah 1,39 menit, rata-rata pemahaman adalah $83,07 \%$ dan rata-rata Kemampuan membaca efektif siswa adalah 186,59 KPM. Rata-rata Kemampuan membaca efektif ini masih belum mencapai kompetensi yang diharapkan dalam Kurikulum Tingkat Satuan Pendidikan (KTSP), sehingga Kemampuan membaca efektif siswa pada uji KME ketiga ini masih tergolong lambat (kurang memadai).
Pada uji KME keempat, teks berjudul "Hagemoni Jepang" yang terdiri atas 327 kata. Rata-rata waktu yang dibutuhkan dalam membaca adalah 1,55 menit, rata-rata pemahaman siswa adalah $84,61 \%$, dan rata-rata Kemampuan membaca efektif siswa adalah 188,60KPM. Jadi, rata-rata Kemampuan membaca efektif siswa masih tergolong lambat (kurang memadai).

Pada uji KME kelima, wacana yang digunakan terdiri atas 318 kata yang berjudul "Islam Cinta Pertamanya". Ratarata waktu yang digunakan oleh siswa adalah 1,26 menit, rata-rata pemahaman siswa mengalami peningkatan yang menjadi $88,46 \%$ dan rata-rata Kemampuan membaca efektif siswa adalah 231,81 KPM, sehingga dapat disimpulkan bahwa Kemampuan membaca efektif siswa masih tergolong lambat (kurang memadai).

Uji KME keenam, wacana terdiri atas 307 kata dengan judul "Manfaat Nanas untuk Kesehatan". Rata-rata waktu yang digunakan siswa adalah 1,34 menit, rata-rata pemahaman siswa adalah $76,92 \%$, dan ratarata Kemampuan membaca efektif siswa adalah 182,06 KPM, jadi dapat disimpulkan bahwa Kemampuan membaca efektif siswa masih tergolong lambat (kurang memadai).

Pada uji KME terakhir, teks terdiri atas 344 kata dengan judul "Tsunami di Aceh". Rata-rata waktu yang diperlukan siswa untuk membaca adalah 1,32 menit, rata-rata pemahaman siswa adalah 90,76\%, dan rata-rata Kemampuan membaca efektif siswa adalah 241,2 KPM. jadi dapat disimpulkan bahwa Kemampuan membaca efektif siswa masih tergolong lambat (kurang memadai). 
Volume 2, Nomor 2, Juli 2020 ISSN 2655-3031 (P), 2655-7851 (O)

Dari 7 kali uji KME yang telah dilaksanakan menunjukan bahwa rata-rata waktu yang digunakan untuk membaca adalah 1,43 menit, rata-rata pemahaman adalah $82,52 \%$, dan rata-rata Kemampuan membaca efektif siswa adalah 193,86 KPM. jadi dapat disimpulkan bahwa, rata-rata Kemampuan membaca efektif siswa SMA N 10 kelas Xc masih tergolong lambat (kurang memadai).

Ketiga Sekolah Menengah Atas Negeri di atas sudah cukup untuk mewakili 10 sekolah yang ada di Kota Bengkulu yang mewakili sekolah berakreditasi tinggi, sedang, dan rendah.

Dari hasil penelitian dari ketiga Sekolah Menengah Atas Negeri Kota Bengkulu, dapat disimpulkan bahwa ratarata waktu siswa untuk membaca adalah 1,62 menit, rata-rata pemahaman siswa adalah 70,03 \%, dan rata-rata Kemampuan membaca efektif siswa kelas $X$ adalah 156,09 KPM. Rata-rata kemampuan membaca efektif ini masih belum mencapai kompetensi yang diharapkan dalam Kurikulum Tingkat Satuan Pendidikan (KTSP), sehingga Kemampuan Membaca efektif siswa pada uji KME ini masih tergolong lambat (kurang memadai).

\section{Kebiasaan Membaca Siswa}

Dari hasil angket yang diberikan kepada tiga Sekolah Menengah Atas Negeri Kota Bengkulu, kebiasaan-kebiasaan membaca siswa dapat digambarkan bahwa, dari 82 responden, 76,82 \% siswa SMA N Kota Bengkulu membaca setiap hari dan $23,17 \%$ siswa yang menjawab tidakmembaca buku setiap hari. Jadi, kebanyakan siswa membaca setiap hari.
Dilihat dari lingkungan siswa, ternyata lingkungan yang senang membaca dan tidak senang membaca hampir berimbang. Terbukti dari jawaban responden yang menjawab 52,43\% lingkungan siswa senang membaca dan $47,56 \%$ lingkungan siswa tidak senang membaca.

Siswa kelas $\mathrm{X}$ di Kota Bengkulu ternyata sangat jarang membaca di perpustakaan. Terbukti dari responden yang menjawab $14,63 \%$ siswa yang sering membaca di perpustakaan dan $85,36 \%$ siswa yang menjawab “tidak".Alasan responden yang membaca karena paksaan atau keperluan lebih sedikit. Terlihat jawaban responden yang menjawab membaca karena paksaan atau keperluan terdiri atas 30,48\% dan yang menjawab sebaliknya, yaitu 69,51\%.Siswa ternyata lebih menyukai membaca karena kebutuhan. Terlihat dari jawaban responden $62,19 \%$ yang menjawab alasan tersebut dan $37,80 \%$ yang menjawab sebaliknya.Kebanyakan siswa memiliki sedikit kegiatan di luar sekolah, sehingga tidak begitu menghalangi mereka untuk membaca.

Dilihat dari jawaban siswa 35,36\% yang mempunyai banyak kegiatan di luar sekolah sehingga tidak mempunyai waktu untuk membaca dan 64,63\% yang menjawab sebaliknya. Rata-rata siswa lebih menyukai membaca buku yang menghibur dibanding buku ilmiah. Hal ini dibuktikan dari jawaban mereka yang mengatakan "ya" sebanyak $79,26 \%$ dan $20,73 \%$ yang mengatakan “Tidak".Kebanyakan siswa membaca tidak dengan bantuan alat. Terlihat dari jawaban mereka yang menjawab "Ya" sebanyak $17,7 \%$ dan menjawab "Tidak" sebanyak $82,92 \%$.Kebanyakan siswa membaca dengan 
tidak bersuara. Hal ini dibuktikan dari jawaban siswa 25,60\% yang menjawab "Ya" dan 74,39 yang menjawab "Tidak". Rata-rata siswa sudah memahami teknik membaca cepat.

Dilihat dari jawaban mereka yang menjawab "Ya" sebanyak 81,7\% dan yang menjawab "tidak" sebanyak 18,29\%.Mayoritas siswa pernah mengukur kecepatan mereka sendiri. Terlihat dari jawaban mereka yang menjawab "Ya" sebesar 70,73\% dan yang menjawab "Tidak" sebanyak 29,26\%. Dari segi kepuasan terhadap kecepatan membaca mereka sendiri, ternyata kebanyakan responden menyatakan belum puas. Hal ini dilihat dari jawaban mereka yang menyatakan sudah puas sebanyak $34,14 \%$ dan menyatakan sebaliknya, yaitu sebesar $65,85 \%$.Intensitas waktu untuk berlatih meningkatkan kecepatan membaca ternyata hampir seimbang antara yang menjawab sering (Ya) dan yang menjawab jarang (tidak). Hal ini terlihat dari jawaban responden yang menjawab "Ya" sebesar 46,34\% dan jawaban tidak sebesar 53,65\%.Kebanyakan guru sering memberikan tugas baca di rumah. Terlihat dari jawaban responden yang menjawab "Ya" sebesar 58,53\% dan "Tidak" sebesar 41,46\% .Mayoritas responden lebih menyukai mencari informasi melalui internet dibanding membaca buku.

Hal ini dibuktikan dari jawaban siswa yang lebih menyukai buku sebesar $36,58 \%$ dan Internet sebesar $63,41 \%$. Ternyata siswa kebanyakan mengulangi bacaan yang kurang ia pahami. Terlihat dari jawaban siswa yang menjawab "Ya" sebanyak 84,14\% dan "Tidak" sebesar 15,85\%.Rata-rata siswa mencari arti kata dalam kamus jika mereka tidak mengerti suatu kosakata. Hal ini dibuktikan dari jawaban mereka yang menjawab "Ya" sebesar 76,82\% dan "Tidak" sebesar 23,17\%.

\section{Hasil Wawancara Metode Pengembangan Keterampilan Membaca Cepat}

a. SMA N 10 Kota Bengkulu

Salah satu usaha yang dilakukan oleh guru untuk meningkatkan kecepatan membaca siswa adalah pemberian tugas baca di rumah baik itu buku, koran dan sebagainya.Setiap kali pengukuran Kemampuan efktif membaca siswa selalu diukur dengan metode pengukuran membaca cepat. Salah satu cara yang digunakan oleh siswa untuk memperoleh suatu kosakata baru yaitu memaknai arti kosakata tersebut melalui konteks kalimat.Cara yang digunakan guru dalam memotivasi siswa agar mereka membaca dengan cepat adalah melalui nilai. Siswa dituntut untuk memiliki nilai yang bagus sehingga siswa berusaha untuk meraih nilai yang terbaik dengan berlatih membaca cepat. Intensitas waktu yang digunakan guru untuk melatih siswanya dalam membaca cepat tergolong jarang.Guru sendiri mengetahui bahwa penggunaan alat bantu seperti telunjuk akan menghambat kecepatan membaca siswa sehingga, sebelum dilakukan pengukuran Kemampuan membaca efektif siswa diperingatkan terlebih dahulu baik itu teknik membaca cepat yang sudah diajarkannya dan hal-hal yang menghambat kecepatan membaca. 


\section{b. SMA N 1 Kota Bengkulu}

Salah satu usaha yang dilakukan oleh guru untuk meningkatkan kecepatan membaca siswa adalah pemberian tugas kepada siswa untuk mencari wacana di perpustakaan dan menemukan intisari dari bacaan tersebut. Setiap kali pengukuran Kemampuan membaca efektif siswa selalu diukur dengan metode pengukuran membaca cepat. Dan cara siswa memperoleh suatu kosakata baru yaitu siswa dapat menemukan makna kosakata tersebut melalui buku, kamus yang sudah disediakan di perpustakaan, dan internet.Cara yang digunakan guru dalam memotivasi siswa agar mereka membaca dengan cepat adalah menyuruh siswa membaca buku yang mereka senangi baik itu buku fiksi atau nonfiksi.Guru tidak pernah melatih siswanya dalam melatih otot matanya untuk meningkatkan kecepatan membaca siswanya. Namun diajarkan bagaimana teknik membaca cepat dan teknik mengambil intisari. Guru sendiri mengetahui bahwa penggunaan alat bantu seperti telunjuk akan menghambat kecepatan membaca siswa sehingga, sebelum dilakukan pengukuran Kemampuan membaca efektif siswa diperingatkan terlebih dahulu.

\section{c. SMA N 2 Kota Bengkulu}

Salah satu usaha yang dilakukan oleh guru untuk meningkatkan kecepatan membaca siswa adalah pemberian tugas baca untuk menangkap ide pokok bacaan yang dilaksanakan pada hari Jumat di setiap minggunya.Setiap kali pengukuran Kemampuan membaca efektif siswa tidak selalu diukur dengan metode pengukuran membaca cepat karena dinilai agak rumit dan membuat siswa tidak nyaman. Oleh karena itu, siswa diberikan waktu beberapa menit saja untuk membaca.

Cara siswa memperoleh suatu kosakata baru yaitu dengan diberikan wacana yang lebih bervariasi sehingga, jika mereka menemukan beberapa kosakata baru mereka dapat bertanya kepada guru atau mencari makna melalui kamus.Cara yang digunakan guru dalam memotivasi siswa agar mereka membaca dengan cepat adalah melalui nilai. Guru memiliki lembar penilaian yang mengukur setiap tugas siswa.Guru tergolong sering melatih otot mata siswanya karena $50 \%$ ujian nasional terdiri atas wacana. Guru sendiri mengetahui bahwa penggunaan alat bantu seperti telunjuk akan menghambat kecepatan membaca siswa. Namun aturan tersebut dianggap tidak terlalu penting. Sebab, penggunaan alat bantu bergantung pada individu masing-masing. Sebagian orang dapat membaca dengan cepat dengan menggunakan alat atau sebaliknya sehingga siswa tidak begitu diperingatkan mengenai hal-hal yang menghambat kecepatan membaca.

\section{Simpulan}

Berdasarkan hasil penelitian yang telah dilaksanakan mengenai Kemampuan membaca efektif siswa kelas X SMA N Kota Bengkulu, diketahui bahwa, rata-rata pemahaman siswa kelas X SMA N 10 Kota Bengkulu adalah 82,52 \%, siswa SMA N 1 Kota Bengkulu adalah 57,93 \% dan siswa SMA N 2 Kota Bengkulu adalah 82,52\%. Sedangkan rata-rata kemampuan membaca efektif siswa kelas X SMA N 10 Kota 
Volume 2, Nomor 2, Juli 2020 ISSN 2655-3031 (P), 2655-7851 (O)

Bengkulu adalah 162,59 kata per menit, siswa SMA N 1 Kota Bengkulu adalah 111,827 kata per menit, dan siswa SMA N 2 Kota Bengkulu adalah 193,86 kata per menit. Jadi, dapat disimpulkan bahwa ratarata pemahaman siswa kelas X SMA N Kota Bengkulu adalah $70,03 \%$ dan rata-rata Kemampuan membaca efektif (KME) siswa kelas X SMA N Kota Bengkulu adalah 156,09 kata per menit, hal ini masih belum mencapai masih kompetensi yang diharapkan dalam Kurikulum Tingkat Satuan Pendidikan (KTSP) yang menuntut 250 kata per menit, sehingga rata-rata Kemampuan Membaca efektif siswa kelas X SMA N Kota Bengkulu masih tergolong lambat (kurang memadai).

\section{Daftar Pustaka}

Andra, V. 2019. KORELASI ANTARA KEMAMPUAN MEMBACA KRITIS DENGAN KEMAMPUAN MENULIS ARGUMENTASI SISWA KELAS VII A SMP NEGERI 9 KOTA BENGKULU. Disastra: Jurnal Pendidikan Bahasa dan Sastra Indonesia, $\quad$ 1(1), 77-86. doi:http://dx.doi.org/10.29300/disastra. $\underline{\text { v1i1.1904 }}$

Azhari. 2011. Ganbatte:Meneladani Karakter Tangguh Bangsa Jepang. Bandung: Grafindo

Eliya, Ixsir and Sodik, Achmad Ja'far (2019)

$\begin{array}{lr}\text { PENGUATAN } & \text { KEILMUAN } \\ \text { MAHASISWA } & \text { MELALUI } \\ \text { GERAKAN SADAR } & \text { LITERASI } \\ \text { DALAM UPAYA MENANGKAL }\end{array}$

RADIKALISME DAN BERITA HOAKS DI MEDIA SOSIAL. In: International Seminar on Islamic Studies, 28 Maret 2019, IAIN Bengkulu.

Ezokanzo, Tethy, dkk. 2009. Hikari No Michi: Catatan Cinta Mualaf dari Negeri Matahari Terbit. Bandung: Lingkar Pena

Friantary, H. (2019). BUDAYA MEMBACA SEBAGAI UPAYA PENINGKATAN KUALITAS HIDUP MASYARAKAT. Disastra: Jurnal Pendidikan Bahasa dan Sastra Indonesia, 1(1), 66-70. doi:http://dx.doi.org/10.29300/disastr a.v1i1.1485

Heriadi, Meddyan, Susetyo Susetyo, and Trianto Agus. Hubungan antara minat baca dengan kemampuan menulis prosa mahasiswa S1 pendidikan bahasa dan sastra indonesia fkip universitas bengkulu tahun ajaran 2013/2014. Diss. Universitas Bengkulu.

King, Jamie. 2010.111 Konspirasi Menghebohkan Dunia. Bogor:RAS

Mulyasa.2006. Implementasi Kurikulum 2004:Panduan Pembelajaran KBK. Bandung: Remaja Rosda Karya.

Nurrhadi, dkk. 2005. Bahasa dan Sastra Indonesia untuk SMP/MTS Kelas IX. Jakarta: Erlangga.

Nurgiyantoro, Burhan.1995. Penilaian dan Pengajaran Bahasa dan Sastra 152 
Volume 2, Nomor 2, Juli 2020

ISSN 2655-3031 (P), 2655-7851 (O)

Indonesia. Yogyakarta: BPEE.

Sugiyono.2009. Metode Penelitian

Pendidikan. Bandung: Alfabeta.

Syamsudin, dkk. 2007. Metode Penelitian

Pendidikan Bahasa. Bandung:

Remaja Rosdakarya.

Tampubolon, DP. 1990. Kemampuan

Membaca, Teknik Memabaca Efektif

dan Efisien. Bandung: Angkasa. 